\author{
Krzysztof REJMAN ${ }^{1}$ \\ Krzysztof CZUBOCHA ${ }^{2}$
}

\title{
CULTURAL FOUNDATIONS FOR NEOLIBERAL CAPITALISM: CONSUMER AND CORPORATE CULTURE
}

\begin{abstract}
The authors' considerations are based on the hypothesis that contemporary capitalism is not the recreation of $19^{\text {th }}$ century free market capitalism but an ideological system supporting mainly the interests of multinational companies. The neoliberal agenda is based also on cultural foundations and peoples' economic choices are influenced by cultural factors. The overarching logic of neoliberal capitalism boils down to profit maximization and consumption. When this logic was internalized by people, they became unconscious followers of the rules imposed upon them by capital owners. According to neoliberal ideology, corporate culture should to be applied to every domain of personal and social life. Interpersonal relations and marriage have become commodified as well. As a result, the state of mental health of the population has worsened and people have failed to achieve lasting satisfaction. The purpose of the paper is to demonstrate from sociological point of view in what way neoliberal values pervade numerous domains of both social and personal life bringing about negative consequences.
\end{abstract}

Keywords: consumerism, consumer capitalism, corporate university, debt crisis.

\section{INTRODUCTION}

Neoliberal economists claim that selfish individuals should compete among themselves to achieve optimal economic results. Their choices are based on full information and result in the maximization of profits. Sociologists and anthropologists regard this economic theory as 'providential' for nobody is able to explain in what way "the invisible hand of the market" works (Herzfeld, 2004, p. 144). From sociological perspective power relations, uneven access to information, and herd behavior undermine the basic tenets of the neoliberal economic theory. The sociological theory of economic field explains in what way legal regulations support the interests of the biggest market players. What is more, the most powerful economic players are able to influence cultural production creating dominant discourses and instilling into people values which support the interests of capital owners. From the 1960 onwards the term leisure society was used to denote the new condition of life in the

${ }^{1}$ Krzysztof Rejman, DSc, PhD, Associate Prof., professor at Rzeszów University of Technology, Faculty of Management, al. Powstańców Warszawy 12, 35-959 Rzeszów, e-mail: k.rejman@ @rz. edu.pl. ORCID: 0000-0001-6790-8775.

${ }^{2}$ Krzysztof Czubocha, senior lecturer at State Higher School of Technology and Economics in Jarosław, Faculty of International Relations, ul. Czarnieckiego 16, 37-500 Jarosław, corresponding author, e-mail: krzysztof.czubocha@pwste.edu.pl. ORCID: 0000-0002-9266-5178. 
advanced societies of the West. Modern people supposedly ceased to be preoccupied with work as material well-being became widespread. Instead, they were to concentrate on freedom, self-realization, self-improvement, self-development and consumption. The ideal of egalitarian and democratic society was promoted in the U.S. which was epitomized by such slogans as 'the American Dream', or embourgeoisement (Rojek, 2013). These processes and phenomena were taking place in a specific cultural context which is defined as the condition of postmodernity (Lyotard, 1984). Jameson (1985) points to the simultaneous emergence of consumer capitalism and postmodernism. Their mutual relationship lies in the fact that postmodernism enables the reproduction of consumer capitalism.

\section{INTERNAL CONTRADICTIONS OF NEOLIBERAL CAPITALISM}

From sociological point of view economic neoliberalism is a political project which does not eliminate state intervention but concentrates it in certain fields. Free market capitalism is a construct which supports the interests of the biggest market players fostering mergers and acquisitions. Bourdieu (2005) created the theory of economic field which assumes that branches of national economy, whole national economies and world economy can be regarded as fields which means that they are entities governed by internal rules of the game. Within fields there exist constant struggle for overpowering business competitors also by using unfair methods. The biggest players try to influence legislation and state functionaries to limit competition on the part of incumbent companies which may lead to regulatory or state capture. Such distortions of the market are integral part of capitalism and as a result, there is no perfect competition. Economic sociology provides important insights into market processes stressing the importance of power relations while creating markets. There exists status hierarchy within every market. Markets have structures created by power relations and they cannot be conceptualized as networks within the interactionalist approach (Swedberg, 2003).

There is no equality between capital owners and consumers within economic fields as well. Consumers are controlled by consumer culture as the use of force has been replaced by seduction. What is the connection between consumption, leisure and contemporary capitalism? A massive increase in labor productivity in the first half of the $20^{\text {th }}$ century led to a crisis of overproduction, putting in jeopardy capital owners' gains. As it was necessary to find buyers for mass-produced goods, laborers became the consumers of goods which they had produced. The problem of enormous surplus industrial capacity occurred in a particularly stark dimension after World War II in the United States due to reduced demand for products related to the conduct of war. In such circumstances consumer society was created in the United States. Classical economic theory indicated that people consume in order to satisfy their basic needs, which include food, shelter and clothing. These theories are no longer relevant in the age of postmodern society and the consumption-based economy. Modern capitalism artificially drives human needs to entice them to buy ever more. The result is conspicuous consumption (often on credit). Gathering financial assets in bank accounts no longer brings prestige (Holt, Schor, 2000).

The most important internal contradiction of neoliberal capitalism consists in the fact that it supports capital owners or the supply side of the economy and in consequence, the labor force is not able to consume the economic output. People are expected to consume more and wages have stagnated since the 1970s. Consumption accounts for up to 70 per cent of GDP in the most developed countries. Therefore, a collapse in demand brings about 
economic crisis. During the post-modern era capital owners intend to engage people as consumers rather than workers which exacerbates economic imbalances. Therefore, enticing people to consume can be achieved by fostering competition among consumers for social status resorting to fashion, planned obsolescence of products and advertising. The problem of overproduction did not exist during Fordism as the labor force disposed of sufficient income to consume economic output. Since the 1970s, however, real wages stagnated which resulted in the crisis of overproduction. Nominal GDP figures are misleading as they do not account for income inequalities and state expenditure. Economic neoliberalism benefits the richest people who, however, fail to foster demand. Instead, they tend to invest in the real estate or financial assets inflating bubbles. Spending cuts and labor market deregulation also reduce the purchasing power of consumers. Underpaid labor is, in turn, encouraged to consume on credit. That explains why the support for the richest contributes to economic imbalances (Faik, 2015). The problem of insufficient demand could be solved only by creating artificial needs or encourage people to consume ever more competing for social status (e.g. buying luxury goods). As people did not dispose of sufficient income, they were enticed to buy on credit. It was possible as the value of real estate was increasing until 2008. Americans took credits against the growing value of their homes and sub-prime mortgages were offered to ever poorer consumers. When the value of their real estate collapsed after 2008 not only consumers but also the banking sector were badly affected. The current financial and economic downturn was initiated by the sub-prime credit crisis (Wisman, 2013). The Fed tries to improve the economic situation by lowering interest rates with the aim to ease the burden on indebted homeowners. An economist, Fekete (2014), is critical of this policy writing that:

The source of confusion is that a rate-cut is dressed up as if it were helping the homeowners to cope with the financial burden when the exact opposite is the case! In truth, the value of the cash flow of wages has been rendered inferior by the rate cut. It has lost so much of its debt-liquidating power. QE pushes labor deeper in debt and ZIRP (Zero Interest Rate Policy) means perpetual bondage for labor. It is modern slavery. 21st century slaves may well 'own' their homes, their cars, their freezers, etc., but their mortgage debt, their auto-loans, their credit card debt are just so many evidences of indenture of slavery with absolutely no hope of emancipation under QE and ZIRP.

Neoliberal economists argue that the current global economic crisis can be resolved by an increase in demand. Therefore, employees should be provided with low-cost loans to enable them to consume more. Capital owners do not intend to raise wages, which would increase the purchasing power of the population. Hence, the aggressive advertising of consumer credit by banks. Some economists claim that the problem of insufficient demand can be remedied by giving money to consumers (Blyth, Lonergan, 2014). The Fed, however, has chosen to support the banking sector or Wall Street instead of the consumers or Main Street (Borofsky, 2013). In case of the euro-area crisis, ECB has shifted debt-holding from the banking sector to the taxpayers. The Greek and Irish bailouts as well as rescue packages for Spain and Portugal were engineered to save the banks which held foreign debt. In the case of Greece, the private banks' exposure to Greek debt was substantially reduced by selling the debt mostly to the euro-area governments, or the taxpayers (mutualization of debt within the Eurozone). Before the crisis private banks owned the vast majority of Greek 
government bonds. They have reduced their holdings of Greek debt by about 85 per cent. The proposed policy of austerity to remedy the crisis limits even more the spending power of consumers as wages in the public sector and social spending are cut (Mercille, 2015).

The support of the rich since the 1970s consisted also in decreasing the tax burden on business. The biggest corporations often moved their operations to poor countries and funneled profits to tax havens. Resulting budget deficits were financed by sovereign debt. After 2008 the debt burden was so high that it has become non payable if one factors in liabilities resulting from medical care and pensions. In spite of this, the rich have been assisted by nation states and international organizations once more in the form of bailouts and quantitative easing or QE. It was said that QE would increase the amount of money in the real economy leading to economic recovery. In practice, easy monetary policy benefited mostly financial capital feeding bubbles in several asset classes. The richest one percent of the population in the U.S. owns over 40 per cent of the nation's wealth. Thus, capital owners do not intend to increase labor force purchasing power through wage increases (supporting the demand side). Instead, they favor a further increase in the debt burden on the population in the form of either loans or public debt. This model of economic growth will, however, fail to cure the economies of developed countries as the crisis of 2008 demonstrated. This policy will probably lead to another crisis. Mercille (2015) writes that the standard neoliberal economic therapy consisting in cuts in the public sector 'do not hold water'. Government debt can increase as a result of spending cuts as aggregate demand decreases. This, in turn, brings down government revenues and increases welfare and unemployment expenditures.

The above examples demonstrate how supposedly impartial economic rules support the interests of the biggest market players to the detriment of small companies and consumers. After the great financial and economic downturn of 2008 the sociological theory of economic field has been validated. Sociologists have criticized neoliberal capitalism for a long time, but until 2008 they were branded as 'leftist leaning', fact-producing ideologues seeking to undermine the only viable economic and social model based on the neoliberal economic theory which posits that 'there is no alternative'. After the great financial downturn of 2008 sociologists were proven to be right to a large degree and they were joined by numerous renowned economists. Prior to the current crisis it was assumed that economics was the most objective branch of science among the social sciences and the followers of other economic schools were marginalized. After 2008 it has turned out that the neoliberal economic theory was fallacious and ideologized (Weeks, 2013).

Easy monetary policy, spending cuts and consumption on credit have increased social inequalities at the macroeconomic level between capital owners and labor as it amplifies the profits of finance capital and reduces the purchasing power of the labor force in the long term. A similar effect is brought about by buying unnecessary products or their frequent replacement. Increased social inequality in Western countries has become a major political problem as the vast majority of people with stagnant wages increasingly resent the richest one per cent of the population. Social upheavals and unexpected voting patterns may result from this state of affairs. 


\section{CORPORATE AND UNIVERSITY CULTURE - THE CRISIS OF PUBLIC SPHERE}

Traditional bureaucracies were referred to as 'the iron cage', but they provided stability and they were foreseeable. This business model offered both social inclusion and stability enabling the planning of personal development and raising a family. Employees were supposed to adhere to such rules as loyalty, mutual commitment, the pursuit of long term goals, and trust which fostered community spirit (Sennett, 1998; 2006).

Czubocha (2012) writes that:

The new-economy model based on unstable and fragmentary institutions profits people who are self-oriented, think short-term, are able to discard past experience, and are focused on potential ability. Modern companies do not provide social capital or social trust. Employees have to prove constantly that they are still an asset. Human interactions have been replaced with transactions. Resulting emotional traumas affect private and family life of employees. Employers avoid signing traditional contracts with employees. Long-term contracts are often replaced by fixed-time contracts or cooperation with subcontractors (p. 220).

The totality of social life was to be reorganized according to the above mentioned corporate rules within the neoliberal economic model. Public services such as education, health care, pensions were outsourced to corporations. Social problems were reformulated as private concerns. Civil society was to be guided by economic relations in the framework of corporate culture which "becomes an all-encompassing horizon for producing market identities, values, and practices" (Giroux, 2000). The good life, in this discourse, "is construed in terms of our identities as consumers - we are what we buy". (Bryman, 1995).

Neoliberalism marked the crisis of the social. Individuals were treated as the only social units. Individualism led to the crisis of the public sphere. The social value of universities and education was redefined in line with economic liberalism. Students have become 'customers' and consumers and universities turned into service providers which should produce market value. As a result, humanities and the social sciences with the exception of the neoliberal economic theory were regarded as speculative and having no market value. The vast majority of funds were allocated to scientists producing research supporting the neoliberal economic theory on the basis of quantitative research or to research in the field of the natural sciences. The new paradigm involved value-free science, methodological individualism and social justice was limited to its liberal and utilitarian aspects. Knowledge should be treated as venture capital whereas numerous branches of science have no market value.

The faculty is valued on the basis of their ability to secure funds and grants. In this situation critical thinking has become unpopular and scientists criticizing the neoliberal project were branded as 'leftist leaning' and marginalized. To ensure compliance on the part of the faculty the terms of employment were becoming less and less favorable (House, 2014). In this sort of environment "many faculty are demoralized by the new leadership, and they have retreated to their classrooms, unwilling to get involved in the political process because they fear losing their jobs, not getting tenure, or having their salaries frozen." (Giroux, 2000). The ultimate goal of this policy was to quash scientific dissent to the neoliberal version of economy and society. Government agencies promoted quantitative and empirical research, and scientific positivism as qualitative research was deemed to be 
subjective and even subversive. What happened was a powerful and intentional state intervention in the field of science to promote the neoliberal agenda. Western countries steered towards 'audit society' and 'audit culture' (Smith, Hodkinson, 2014). Giroux (2006) writes in this context that:

Within this impoverished sense of politics and public life, the university is increasingly being transformed into a training ground for the corporate workforce, with the loss of any notion of higher education as a crucial public sphere in which critical citizens and democratic agents are formed. In the age of money and profit, academic subjects gain stature almost exclusively through their exchange value on the market.

Corporate funding of universities led to such pathological phenomena as censoring papers unfavorable to business interests or influencing the choice of faculty members by fund providers. This culture slowly corrupted students. In the 1970s the majority of them studied for personal development and now they study mostly for profit as higher education is to reflect management's core values. In this manner corporate universities were created or a broader term the academic-industrial complex should be used. The system of education was used to spread the neoliberal agenda in society and produce a controllable and compliant labor force and uncritical consumers. Higher education produces corporate fodder and consumers instead of critical citizens. However, there is relatively little dissent on the part of students who are highly indebted as student loans deprive them of freedom to question the system (Giroux, 2002). The same applies to scientists who have been disciplined by the policy of funding and employment. Funding policy discourages research critical of neoliberal capitalism and in the U.S. only 27 per cent of faculty enjoy satisfactory terms of employment (Giardina, Newman, 2014).

Finally, it is important to notice that the neoliberal economic theory discredited itself after 2008 and Keynesian massive market intervention. Therefore, one should assume that the neoliberal economic policy has failed and scientific research critical of economic neoliberalism has been vindicated. In spite of this, the interests of capital owners have not been jeopardized and the preachers of neoliberalism have not been sidelined. Neoliberalism has retained its hegemonic status. This conundrum was explained by Plehwe and Walpen (2006) who write that the adherents of economic neoliberalism have created worldwide entrenched networks of scholars, think tanks, NGOs, politicians and business elites who control knowledge production and diffusion. Partisan think tanks and NGOs are often funded by business and they played an important role in spreading the neoliberal agenda outside the capitalist core countries.

\section{CONSUMPTION AS A CULTURAL CODE}

Scientists agree that Western societies were profoundly changed by leisure and consumption. Since the consumer boom of the 1950s working-class families lifestyle was transformed. Peoples' aspirations and expectations changed and they started to believe in the existence of a liberating social system in the U.S. (The Consumer Society, 1997) There is, however, no agreement as to the real significance of these changes. The adherents of neoliberal capitalism claim that consumers have won the upper hand and producers have to compete to fulfill the desires of consumers in order to sell their products and services. Some sociologists subscribe to this view writing about a reflexive agent (consumer). Buying in 
a supermarket is compared to voting. Consumers express in this manner their freedom and choose whatever products they wish. Such opinions were supplemented by other scholars who claimed that traditional social classes disappeared under neoliberal capitalism as consumption patterns became ever more uniform. Free consumers can supposedly actively construct their identities controlling their lives and as a result, they can become whoever they want (Miles, 2006).

Such views are opposed by numerous sociologists in the framework of the sociology of consumption who point out that economists underestimate the role of culture in shaping consumption patterns. Moreover, the multiplicity of goods does not necessarily improve the quality of peoples' lives. Nowadays, people increasingly experience stress and tension connected with opportunity loss resulting from the freedom of choice. In the course of time, computer technology and the Internet will deprive people of freedom by way of electronic automatism (Rojek, 1995). The leisure industry supposedly offers escape, pleasure and fulfillment, but in reality it provides standardized package tours whereas neoliberal thinking referring to leisure underlines self-expression, self-determination, choice and freedom. The addiction to consumer culture results in the culture of overwork bringing negative consequences in the field of physical and mental health. Peoples' lives are centered on working and spending to keep up with the Joneses. People work longer as time is money (Schor, 1993). Stebbin (2008), in turn, points out that there is a difference between serious and casual leisure. The former term refers to the improvement in skills leading to better career prospects whereas the latter form is desultory and opportunistic.

There are two important texts revealing the hidden dimension of contemporary capitalism. Both texts argue that the condition of postmodernity coincided with consumer capitalism to support it by way of forging unbridled consumption. Baudrillard (1999) writes that a cultural climate was created in which consumers cannot stop consuming as their social status, personal well-being and even finding a partner requires spending money. A new system of signs developed which is connected with consumption. Every object has a signvalue and a use-value. Commodities are valued for their symbolic value rather than their use-value. Labor force has been disciplined for employees are dependent on capital owners consuming on credit which makes them even more vulnerable. Values have been replaced with desires or the biological order. Jameson (1984), in turn, claims that it is a mistake to conceptualize postmodernism as a cultural phenomenon. Instead, it is above all a conception with economic underpinnings. Namely, postmodernism supports consumer capitalism contributing to the creation of consumer society. The cultural logic of postmodernism involves cultural changeability and the lack of artistic canons. This, in turn, influences consumer products which change more and more often in terms of design forcing consumers to replace them very often. Usually it boils down to a new design rather than new qualities of products.

Another set of problems pertains to class divisions on the basis of consumption. Nearly every individual intends to upgrade his or her social status and it is possible by way of consuming more and more expensive goods and services. Bourdieu (1984), was of the opinion that social distinction was based on taste. People belonging to different social classes were supposedly characterized by different tastes with reference to consumption. This view is questioned nowadays but it is underlined that class divisions not only persist but they have actually increased during neoliberal capitalism. People compete for money, prestige and power. The distinction between the rich and poor can be attributed to the price of goods and services they consume. The term conspicuous consumption is applicable with this respect. The rich distance themselves from the poor by buying luxury goods as having money 
is associated with prestige in Western countries. Some people choose to rebel, rejecting consumption but the majority of them are malleable, weak fools, merely pawns in the hands of capital owners. On the one hand, consumerism offers personal freedom whereas on the other hand it imposes a hidden order which supports the capitalist system. In other words, structure dominates agency by way of the ideology of consumption (Miles, 2006). The domination is achieved by fostering competition among people. Fashion, advertising and planned obsolescence of products entice people to consume ever more (Corrigan, 1997).

Sociology comes to a conclusion that people compete for resources (economic capital) and seek to obtain the highest possible social status. In this context, buying objects has a double meaning as it refers to both satisfying the needs and acquiring a place in social hierarchy. The symbolic significance of purchased goods is based on demonstrating the social position of the individual. As a result, the advertising industry presents objects as the providers of social status and prestige. The individual demonstrates his or her social status by way of possessions. It is a sort of communication with external world. Through consumption the individual is able to remain within his or her reference group (confirmation) or aspire to belong to another group. Moreover, by buying goods people build their identity. Material goods allow buyers to build self-esteem, pride and satisfaction. Luxury goods increase peoples' self-esteem and arouse neighbors' jealousy and admiration (Szul, 2006). This is the social logic of consumption. Everyone is forced to submit to this system of communication despite the fact that most often people do not realize its existence (Baudrillard, 1999). Consumption encompasses new spheres of human life. Services have acquired the same status as objects. Thus, tourism and services offered by the beauty industry also communicate the social status of the individual. The cult of beauty requires ample financial means as beauty products, spas and plastic surgeries are expensive.

Practicing consumer culture takes place in the temples of consumption and shopping centers play a major role in this respect. Shopping consumes more and more time and it is considered to be a form of leisure activity. The rise of mall culture has been possible as a result of secularization, individualism and consumerism. Shopping malls and other means of consumption play the role of medieval temples and going shopping is like pilgrimage. By choosing products people can create their identities. Increasingly people think of themselves as "wearers of certain logos or frequenters of certain restaurants, resorts, and other temples of consumption or shopping shrines" (Cussack, Digance, 2008). Big shopping centers have ceased to be just shops. Their attractiveness consist in a wide range of facilities. Apart from shops, restaurants, beauty parlors, cinemas even chapels are offered. The biggest shopping centers have become places of tourist destinations and trips (pilgrimages). Such places are often attractive architecturally, create a sense of luxury and can cover an area of several dozen football pitches (Cussack, Digance, 2008).

\section{COMMERCIALIZATION OF INTERPERSONAL RELATIONS}

From medical point of view the most worrying phenomenon associated with consumer culture is the commercialization of interpersonal relations. As a result of profit maximization, the emotional approach to interpersonal relations have been replaced by a culture with economic underpinnings. People increasingly enter into relationships, including intimate ones, on the basis of economic calculations. People are evaluated on the basis of their marketability. Entering into relationships, people evaluate "the exchange value of the relational investment". Market-style marriages are arranged by judging costs and benefits. If one of 
the partners fails to contribute to the consumer aspirations of the other partner s/he runs the risk of being jilted. This cultural code results in social anxiety disorders. In particular 12-15 per cent of the population suffers from social phobia. Commercialized marriage results in depression. The loss of the local social sphere creates needs for drugs. Medical consumption is stimulated in this manner. Numerous therapies flourish in this environment (Schumaker, 2001). This state of affairs is best summarized by Schumaker (2001) when he writes:

When the consumer program is fully internalized, it becomes a social vision that, with ongoing media assistance, insulates members from a conscious awareness of their loneliness. Consumption as a cultural code has become so prominent that few members find themselves capable of the healthy disobedience required to develop a personal code that makes ample room for the "other". Even if this were possible, it is likely that self-motivated consumer defiance would have the reverse effect of increasing the amount of estrangement experienced as a result of this cultural disobedience.

The ideal of romantic love has been employed to enhance consumption. Consumption acts are multiplied and affirmed through romance. Numerous consumption acts have economic underpinnings, but are portrayed as intimate relationships between people. For instance the car ride is presented by the advertising industry as a romantic experience full of excitement. Women should always apply beauty products for there are multiple possibilities of romance in everyday situations. By way of glamour, excitement and intimacy love has attained economic underpinnings and has been equated with consumption. The new utopia consisted in bundling together love for everyone (eroticism) and consumption for all (wealth) with the democratic ethos (equality). Family, intimacy and sexuality have been redefined to suit this utopia. The commodification of romance involved the central role of consumption which would guarantee the intensity of relationships (Illouz, 1997). Dating and the declaration of love has become impossible without gifts or consumption. Commodities acquired a romantic aura. Romantic holidays in exotic places epitomize the connection between eroticism, tourism and consumption. Children, however, reduce a couple's possibility of consumption and leisure time so often they are not welcome in hotels. The American Dream has become associated with the commodification of love. Couples are presented in advertisements as tourists, at an expensive restaurant or in a luxury hotel. The ideal of romantic love has become to be associated with good look and affects ever older people resulting in a cult of beauty. As a result, the beauty industry emerged as an important branch of industry (Turner, 2011). Love is part of secular religion and its commodification suggests eroticism and consumption can fulfill all needs of people (Beck, Beck-Gernsheim, 1995).

In spite of a broad choice of consumer products, and ever higher standard of living, the modern man is not happy, feeling lonely, suffering from anxieties, depression and addictions. People compete with others instead of sharing things and experiences. This, in turn, leads to selfishness, because the desire to outperform others causes antagonisms between people. The attitude "the more a have, the more I am" leads to a desire to exploit other people. Sellers intend to rip off clients and employers tend to exploit employees. The full satisfaction of consumer needs is impossible leading to jealousy and frustration. Rapid economic changes and competition makes the modern man insecure as s/he may lose his or her social position. In uncertain economic times, self-conception based on material goods raises 
fears and anxieties as in the event of an economic breakdown peoples' lives may be in ruins (Fromm, 1999). In addition, the race to have more and more luxury goods never ends as the spread of a product reduces its symbolic value (Warde, 2006). This race allows capital owners to gain profit but it fails to give a lasting satisfaction to the consumer who tries to make up for the lack of committed relationships by consumer conquests or allegiance to prestigious brand names (Schumaker, 2001).

\section{CONCLUSIONS}

The ascendancy of neoliberal corporate culture into various facets of peoples' lives was to create a new man within a market society. People were promised to achieve lasting satisfaction on condition of submitting to the profit-based consumer culture. After the great financial and economic downturn of 2008 it turned out that consumers were misled as class divisions were not transcended and consumption on credit ended with a failure. To the contrary, wages have stagnated and social inequalities have increased for the last quarter of century. As a result, people are frustrated due to economic hardships. They also suffer from mental disturbances and seek therapies to remedy their problems not realizing that the lack of proper personal relations and the commercialization of life is to blame for the disorders. Overconsumption results in overwork, as people work more to consume more. In this way, in spite of growing productivity, the amount of leisure time at the disposal of people has been reduced. Consumers are manipulated into believing that it is in their own interest to engage in the consumer culture whereas in fact, the culture fosters the interests of capital owners supporting neoliberal capitalism. Maintaining the current economic model based on overconsumption is harmful from social and environmental point of view. The effects of this model include economic and financial crisis, the depletion of Earth's resources and environmental degradation. Consumer capitalism increases social inequalities jeopardizing social order. The owners of capital are enriching themselves at the expense of consumers who are not able to achieve happiness by way of consumption. The neoliberal economic model based on consumption is not viable and it has led to the current economic and financial downturn. International business intends to transform the modern man into an uncritical follower of unbridled consumption in the interest of capital owners in order to enable profit enhancement from business activities. Postmodern condition results in nomadism. Uprooted and disoriented people pursue unrealistic goals being subjected to hidden management. In such situation, it becomes particularly important to shape the young not as consumers but rather as conscious citizens understanding the sources of the current economic situation and the scale of manipulation they are subjected to.

\section{REFERENCES}

Baudrillard, J. (1999). The Consumer Society: Myths and Structures. London: Sage. Beck, U., Beck-Gernsheim, E. (1995). The Normal Chaos of Love. Cambridge: Wiley. Blyth, M., Lonergan, E. (2014). Print Less But Transfer More: Why Central Banks Should Give Money Directly to the People. Foreign Affairs 93(5), [Access: 26.04.2016]. Access on the internet: https://www.foreignaffairs.com/articles/united-states/2014-08-11/print-less-transfer-more. Borofsky, N. (2013). Bailout: How Washington Abandoned Main Street While Rescuing Wall Street. New York: Free Press.

Bourdieu, P. (1984). Distinction: A Social Critique of the Judgment of Taste. London: Routledge and Kegan Paul. 
- (2005). Principles of economic anthropology [In:] Smelser, N.J., Swedberg, R., eds., The Handbook of Economic Sociology. Princeton: Princeton University Press.

Bryman, A. (1995). Disney and his Worlds. New York: Routledge.

Carrigan, P. (1997). The Sociology of Consumption: An Introduction. London: Sage.

Cussack, C.M., Digance, J. (2008). "Shopping for a Self": Pilgrimage, Identity-formation and Retail Therapy [In:] John, G.St. ed., Victor Turner and Contemporary Cultural Performance. New York: Berghahn Books.

Czubocha, K. (2012). Age Discrimination in the Context of Globalization, Modernization and the Labor Market [In:] Zieliński, Z.E. ed., Rola informatyki w naukach ekonomicznych $i$ spotecznych. Kielce: Wyższa Szkoła Handlowa w Kielcach.

Faik, J. (2015). Global Economic Accounting and Its Critics: Objective Approaches [In:] Glatzer, W., Camfield, L., Møller, V., Rojas, M., Global Handbook of Quality of Life: Exploration of Well-Being of Nations and Continents. Dordrecht-Heidelberg-New York-London: Springer.

Fekete, A. (2014). The Counterproductive Monetary Policy of the Fed: Sowing Inflation, Reaping Deflation [Access: 15.03.2015]. Access on the internet: http://www.professorfekete. com/articles/AEFCounterProd MonetaryPol Fed.pdf.

Fromm, E. (1999). Mieć czy być. Poznań: Wyd. Rebis.

Giardina, M.D., Newman, J.I. (2014). The Politics of Research [In:] Leavy, P., ed., The Oxford Handbook of Qualitative Research, Oxford-New York: Oxford University Press.

Giroux, H. (2000). Impure Acts: The Practical Politics of Cultural Studies. New York: Routledge.

- (2002). Neoliberalism, Corporate Culture, and the Promise of Higher Education: The University as a Democratic Public Sphere. "Harvard Educational Review" 72(4).

- (2006). America on the Edge: Henry Giroux on Politics, Culture, and Education. New York: Palgrave Macmillan.

Herzfeld, M. (2004). Antropologia. Praktykowanie teorii w kulturze i społeczeństwie. Kraków: Wydawnictwo Uniwersytetu Jagiellońskiego.

Holt, D.B, Schor, J.B. (2000). Introduction. Do Americans Consume Too Much? [In:] Holt, D.B., Schor, J.B., eds., The Consumer Society Reader). New York: The New Press.

House, E.R. (2014). Ewolucja jakościowa i zmiana polityki społecznej [In:] Denzin, N.K., Lincoln, Y.S., eds., Metody badań jakościowych: vol. 2. Warszawa: PWN.

Illouz, E. (1997). Consuming the Romantic Utopia: Love and the Cultural Contradictions of Capitalism. Berkeley: University of California Press.

Jameson, F. (1984). Post-Postmodernism: or, The Cultural Logic of Late Capitalism. "New Left Review" 146.

(1985). Postmodernism and Consumer Society [In:] Foster H., ed., Postmodern Culture. London: Pluto Press.

Loytard, J.F. (1984). The Postmodern Condition: A Report on Knowledge. Manchester: Manchester University Press.

Mercille, J. (2015). The Political Economy and Media Coverage of the European Economic Crisis: The Case of Ireland. Abingdon: Routledge.

Miles, S. (2006). Consumerism: As a Way of Life. London: Sage.

Goodwin, N.R. Ackerman, F., Kiron, D., eds. (1997). The Consumer Society. Washington: Island Press. 
Plehwe, D. Walpen, B. (2006). Between Network and Complex Organization: The Making of Neoliberal Knowledge and Hegemony [In:] Plehwe, D., Walpen, B., Neuhoffer, G., eds., Neoliberal Hegemony: A Global Critique. Abingdon: Routledge.

Ritzer, G. (2004). Magiczny świat konsumpcji. Warszawa: Wyd. Muza.

Rojek, Ch. (1995). Decentering Leisure: Rethinking Leisure Theory. London: Sage.

(2013). Capitalism and Leisure Theory. Abingdon: Routledge.

Schor, J. (1993). The Overworked American: The Unexpected Decline of Leisure. New York: Basic Books.

Schumaker, J.F. (2001). The Age of Insanity: Modernity and Mental Health. Westport: Praeger. Senett, R. (1998). The Corrosion of Character: The Personal Consequences of Work in the New Capitalism. New York-London: W.W. Norton \& Company.

- (2006). The Culture of New Capitalism. New Haven: Yale University Press.

Sharpley, R., Stone P.R. (2011). Introduction. Thinking about the Tourist Experience [In:] Sharpley, R., Stone, P.R., eds., Tourist Experience: Contemporary Perspectives. Abingdon: Routledge.

Smith, J.K., Hodkinson, P. (2014). Relatywizm, kryteria i polityka [In:] Denzin, N.K., Lincoln, Y.S., eds., Metody badań jakościowych, vol. 2. Warszawa: PWN.

Stebbin, R.A. (2008). Serious Leisure: A Perspective for Our Time. New Brunswick: Transaction Publishers.

Stevenson, N. (2006). Fashion. [In:] Turner, B.S., ed., The Cambridge Dictionary of Sociology. Cambridge: Cambridge University Press.

Swedberg, R. (2003). Principles of Economic Sociology. Princeton: Princeton University Press. Szul, E. (2006). Konsumpcja jako forma zniewolenia człowieka. „Jarosławskie Studia Spoteczne" 1 .

Turner, B.S. (2011). Religion and Modern Society: Citizenship, Secularization and the State. Cambridge: Cambridge University Press.

Warde, A. (2006). Consumption [In:] Turner, B.S., eds., Cambridge Dictionary of Sociology. Cambridge: Cambridge University Press.

Weeks, J. (2013). Economics of the 1\%: How Mainstream Economics Serves the Rich, Obscures Reality and Distorts Policy. London-New York: Anthem Press.

Wisman, J.D. (2013). Wage Stagnation, Rising Inequality and the Financial Crisis of 2008. "Cambridge Journal of Economics" 37(4).

DOI: $10.7862 /$ rz.2019.hss.9

The text was submitted to the editorial office: February 2018.

The text was accepted for publication: March 2019. 